\title{
The Development of the Questionnaire on Health Care Professionals' Attitudes on Accreditation of Health Care Institutions
}

\author{
Gordana D. Marković-Petrović ${ }^{1}$, Gordana B. Belamarić \\ ${ }^{1}$ Department for Specialist and Consultative activities, Primary Healthcare Center Zemun, \\ Belgrade, Serbia \\ ${ }^{2}$ City Institute for Public health Belgrade, Belgrade, Serbia
}

\section{SUMMARY}

Introduction: Accreditation is a procedure for evaluating the quality of work of a health care institution. It is based on the application of the optimal level of established work standards on health care institutions in a particular area of health care (branch of medicine). As health care professionals are the main carriers during the accreditation process of healthcare institutions, it is very important to evaluate the structure and gain insight into the most important components of their positions regarding accreditation, prior to starting this process.

Methods: The study was conducted in two secondary and tertiary level hospitals, one of which is accredited and the other is not. It was designed as an observational study and included a survey of two groups of respondents. The experimental group consisted of employees of a hospital where the process of accreditation had been conducted, while the control group consisted of employees of a hospital where the process of accreditation had not been conducted yet. The survey used an original questionnaire that consists of 23 questions as a tool for measuring the health care professionals' attitudes on accreditation. The data reduction and structural validity evaluation of the aforementioned instrument was performed by principal component analysis, while its relativity was evaluated using the Cronbach's alpha coefficient.

Results: The Questionnaire on Health Care Professionals' Attitudes on Accreditation with the resulting 10 questions has high structural validity (Kaiser-Meyer-Olkin measure of adequacy $=0.909$ ). The total Cronbach's alpha was 0.916 . By analysing the main components of the extracted ten questions, three factors (components) were identified: (1) the Attitude on the Positive Long-Term Impacts of Accreditation on the Planning, Implementation and Changes of the Overall Concept of Health Care, (2) the Attitude on Increasing Professional Affirmation and Improving Work Morale, and (3) the Attitude on Improving Communication and Safety at Work. Health care professionals employed in a hospital that had completed the accreditation had significantly more positive attitudes about the process in all of the aforementioned components compared to employees of a hospital that had not completed the accreditation process. Conclusions: The Questionnaire on Health Care Professionals' Attitudes on Accredi- 
tation has high content and structural validity. By applying it prior to the hospital's accreditation process, potential positive resources within the institution could be assessed, resulting from the positive attitudes of healthcare professionals about accreditation. Also, with this instrument, potential barriers to the successful implementation of accreditation could be assessed, resulting from the predominantly negative attitudes of health professionals about the accreditation process.

Keywords: accreditation, attitudes, healthcare professionals, questionnaire, principal components analysis

\section{INTRODUCTION}

Accreditation is a procedure for evaluating the quality of work of a health care institution. It is based on the application of the optimal level of established work standards on health care institutions in a particular area of health care (branch of medicine) [1]. It is considered to be the oldest and most widespread independent mechanism for the external assessment of the quality of work of health care institutions and is implemented in over 70 countries worldwide. Its goal is to provide safe health services of the highest quality $[2,3]$. As a result of regional and national strategies, the development of the healthcare accreditation programs was intensified in Europe in the 1990s [4].

The accreditation process contributes to ensuring the quality and cost-effectiveness of health care services. It creates equal or approximately equal conditions for the provision of health care services throughout the health care system, as well as establishing consumer confidence, and improving overall health care management [4].

Leadership, human resource management, quality management, organizational culture, and safety directly influence the accreditation process of health care facilities and are linked to the development of health care facilities [5]. A survey on the importance of accreditation conducted at a hospital in Iran has identified leadership and quality management as the most important predictors of quality [6].

However, employees in health care centers are the main carriers of the activities that accreditation entails, and the success of the process directly depends on their motivation and engagement. Various research projects have shown that personal involvement of employees during the accreditation process significantly increases their interest in improving the quality of work of the health care institution as a whole [7].
In addition, employees' views on the accreditation process are important for the implementation of this process, given that team collaboration is critical for completing the accreditation process [8].

Despite the large body of research conducted in this area, there is still insufficient data to form solid conclusions regarding the effects of the accreditation process [9]. This is why health care professionals often express a certain level of scepticism about the effects of the accreditation process. Some of them find the process to be too demanding, bureaucratically oriented and expensive, especially with the admixture of marketing methods and strategies [10]. Moreover, some of the recent studies have indicated that the accreditation process of hospitals is associated with a significant increase in stress levels in health care providers [11].

On the other hand, a study conducted at a recently accredited Danish hospital utilised a semi-structured interview. Its goal was to capture a broader range of employees' experiences. The study showed that employees found that organizational activities had been improved during the preparation for the accreditation process, and that the hospital was better prepared for new initiatives following accreditation [12].

Generally speaking, it is of utmost importance for the validity of the studies examining health care professionals' attitudes that they do not burden themselves with additional obligations during the research. Given the nature of the work they do and the time constraints their work entails, using an openended questionnaire is considered to be an adequate research approach for examining their views and gathering comments related to the evaluation of the accreditation process [13].

Considering the aforementioned facts, it is of utmost importance to examine 
the health care professionals' attitudes regarding accreditation before starting the accreditation process [7]. This fact was one of the leading motives for creating a valid and reliable instrument that would provide data on health care professionals' attitudes and expectations towards the accreditation process.

\section{METHODS}

An observational academic (non-commercial) study examining the health care professionals' attitudes on accreditation, regardless of their own experience of going through the accreditation process, was conducted in February 2016, in Health Center Zvezdara (HC-A) and Health Center Zemun (HC-B). In addition, a cross-sectional study based on the respondents' experience of going through the accreditation process was also conducted. The respondents of this study were divided into two groups: the first group consisted of health care professionals from the hospital that completed the accreditation process (HC-A), and the second group consisted of health care professionals from the hospital that did not complete the process yet (HC-B).

\section{Research subjects}

The survey included two groups of respondents: the experimental group that consisted of employees of a health care institution where the process of accreditation had been implemented (HC-A), and the control group that consisted of employees of a health care institution where the process of accreditation had not been implemented yet (HC-B).

Interviews with health care professionals were conducted over the course of one day. Questionnaires (Appendix 1) were distributed to all of the departments. The estimated time for completion of the questionnaire was 10 minutes.

\section{Measurement instrument applied in research}

A questionnaire, which consisted of questions that were designed to examine health care professionals' knowledge and attitudes regarding the accreditation process, was applied in the survey. The thematic framework for the questionnaire was created on the basis of the literature related to the accreditation process, how- ever, the questionnaire itself was designed as a completely new tool, since no similar research regarding the structural validity the Questionnaire on Health Care Professionals' Attitudes on Accreditation of Health Care Institutions had not been previously done.

Two questionnaire structure included two blocks. The first block included general information about the respondent and it consisted of three questions, two of which were multiple-choice, while respondents were instructed to fill in the blank regarding the question about their age. The second block consisted of 23 questions regarding the health care professionals' attitudes on the accreditation process, its impacts on the organization, planning, implementation, communication on all levels, professional affirmation and employee satisfaction, as well as the quality of health care in the institution. The answers in the second part of the questionnaire were defined by ordinal three-step descending Likert scale (from $0-2$ ), which expresses the degree of agreement with one of the gradients of ordinal scale (0-I agree; 1- undecided; 2- I disagree).

\section{Legal and ethical aspects}

The survey was anonymous in both institutions. All participants signed the Informed Consent. The study was approved by the ethics committees of the institutions where the research was conducted with Permission of the Ethics Committee of the Health Center Zvezdara from 30 May 2015, and Permission of the Ethics Committee of the Health Center Zemun from 17 February, 2016.

\section{Inclusion or exclusion criteria}

The study included: employees of both health care institutions (doctors and nurses), who voluntarily agreed to participate in the study.

The study did not include respondents who had multiple completed answers, or respondents who submitted questionnaires with missing answers.

\section{Description and selection of research sites}

When selecting of the institutions where the research would be conducted, it was taken into account that both institutions should have a similar structure of medical services and medical staff, and that both institutions were 
tertiary levels of health care. In HC-A, 25\% of the total number of employees were doctors, and $75 \%$ were nurses and health care technicians, while in $\mathrm{HC}-\mathrm{B}, 27 \%$ of the total number of employees were doctors, and $73 \%$ nurses and health care technicians.

The first institution was HC-A, in Belgrade, Serbia, which had, prior to the research, already completed the process of accreditation in all organizational statutory and systematization segments, while the second institution HC-B, in Belgrade, Serbia, was chosen since it had not started the accreditation process yet.

\section{Statistical method}

Numerical data sets were described by the arithmetic mean as a measure of the central tendency, as well as by standard deviation measures of the variation between the data set. Data for categorical variables was described by frequency and percentage.

Analysis of the main components was used as a tool of inferential statistics for the assessment of the construct and content validity of the Questionnaire on Health Care Professionals' Attitudes on Accreditation. The relativity of the extracted components and the overall relativity were evaluated by the Cronbach's alpha coefficient. In component extraction, questions with communalities that were less than 0.5 were eliminated. The accepted minimum level of Kaiser-Meyer-Olkin's measure of adequacy was 0.80 , with a minimum total explained variance of 0.70 . The accepted lowest level of Cronbach's alpha coefficient was 0.7 . The Mann Whitney test was used to evaluate differences in numerical continuous variables between different groups of health care

Table 1. Frequency distribution of health care workers surveyed by gender and occupation between two institutions

\begin{tabular}{|c|c|c|c|}
\multirow{2}{*}{ Institution } & \multicolumn{3}{|c|}{ Gender } \\
\cline { 3 - 4 } & & Male & Female \\
\hline \multirow{2}{*}{ HC-A } & $F$ & 52 & 219 \\
& $\%$ & $59.8 \%$ & $56.2 \%$ \\
\hline \multirow{2}{*}{ HC-B } & $F$ & 35 & 171 \\
& $\%$ & $40.2 \%$ & $43.8 \%$ \\
\hline & & \multicolumn{2}{|c|}{ Occupation } \\
\cline { 3 - 4 } & & Doctor & Nurse (Technician) \\
\hline \multirow{2}{*}{ HC-A } & F & 82 & 189 \\
& $\%$ & $53.6 \%$ & $58.3 \%$ \\
\hline \multirow{2}{*}{ HC-B } & $F$ & 71 & 135 \\
\hline Total & $\%$ & $46.4 \%$ & $41.7 \%$ \\
\hline
\end{tabular}

professionals who have/have not undergone the accreditation process. A $\chi^{2}$-test was used to estimate differences in frequency distributions by modalities of nominal variables. Statistical data processing was done in the IBM SPSS Statistics 20 package, New York, USA.

\section{RESULTS}

According to the data from 31 December 2015, At HC-A, 294 doctors and 866 nurses and health care technicians were employed. During 2015, 247,636 medical examinations were performed at HC-A, and 29,037 patients were admitted.

In the same period, 258 doctors and 700 nurses and health care technicians were employed at HC-B. 187,825 medical examinations were performed, and 21,109 patients were admitted.

The study involved 271 subjects from HC-A and 206 subjects from HC-B. The average age of the respondents in the overall sample of 477 health care professionals from both institutions was 43.25 years \pm 8.89 years. There was no difference in the age of the health care professionals surveyed between institutions $(\mathrm{t}$ $=0.867 ; \mathrm{df}=469.836 ; \mathrm{p}=0.386)$. The average age of HC-A subjects was 43.55 years \pm 9.50 years, while the average age of HC-B subjects was 42.85 years \pm 8.01 years. There was no difference between institutions in the frequency distribution of surveyed health workers by gender $\left(\chi^{2}=0.379\right.$; $\left.\mathrm{df}=1 ; \mathrm{p}=0.538\right)$. The frequency distribution of respondents by gender and occupation is shown in Table 1. There was no difference between institutions in the frequency distribution of surveyed health workers by occupational category $(\chi 2=0.951 ; \mathrm{df}=$ $1 ; \mathrm{p}=0.329$ ).

Structural validity, content validity and reliability of the Questionnaire on Health Care Professionals' Attitudes on Accreditation (QHCPAA).

The principal components analysis was conducted on data obtained from 477 health care professionals from both institutions. Ten valid questions were extracted from a total pool of 23 questions. Due to the adjustment of the direction of the newly obtained calibration scale, three questions were recorded by replacing the Likert scale values as follows:

a) value 0 was replaced by 2 ,

b) value 2 was replaced by 0 , and 


\begin{tabular}{|c|c|c|c|}
\hline Questions & Mean & SD & $\mathbf{N}$ \\
\hline $\begin{array}{l}\text { The accreditation process is an opportunity for the hospital to discover its } \\
\text { capabilities, strengths and weaknesses. }\end{array}$ & 0.72 & 0.86 & 477 \\
\hline $\begin{array}{l}\text { After the accreditation process, hospitals can define their goals in an easier } \\
\text { and more realistic manner. }\end{array}$ & 0.75 & 0.88 & 477 \\
\hline $\begin{array}{l}\text { Changes that occur during the preparation for the accreditation process a } \\
\text { short-lived. }\end{array}$ & 1.21 & 0.79 & 477 \\
\hline The accreditation process has a significant impact on hospital PR. & 1.30 & 0.75 & 477 \\
\hline Benefits that the accreditation process brings are unclear to me. & 0.51 & 0.73 & 477 \\
\hline $\begin{array}{l}\text { The accreditation process has the effect of changing the overall concept of } \\
\text { health care protection. }\end{array}$ & 0.82 & 0.93 & 477 \\
\hline $\begin{array}{l}\text { The accreditation process is a significant opportunity for personal and pro- } \\
\text { fessional improvement. }\end{array}$ & 0.19 & 0.53 & 477 \\
\hline Responsibilities at work significantly increase post-accreditation. & 0.73 & 0.84 & 477 \\
\hline $\begin{array}{l}\text { The accreditation process contributes to the increase in work safety of all } \\
\text { employees. }\end{array}$ & 0.74 & 0.844 & 477 \\
\hline $\begin{array}{l}\text { The accreditation process significantly improves communication on all lev- } \\
\text { els. }\end{array}$ & 0.37 & 0.70 & 477 \\
\hline
\end{tabular}

c) value 1 remained the same.

The questions with the recoded answers are:

a) Changes that occur during the preparation for the accreditation process are short-lived;

b) The accreditation process has a significant impact on hospital PR;

c) Benefits that the accreditation process brings are unclear to me.

Descriptive statistics on extracted questions are presented in Table 2.

Data has shown that the obtained QHCPAA consisting of ten questions has high structural validity (Kaiser-Meyer-Olkin measure of adequacy $=0.909 ; \mathrm{df}=45 ; \chi^{2}=$ $3226.590 ; p=0.000$ ). The analysis of the principal components of the ten questions identified three factors or components (Table 3). This measuring instrument has high content validity, as $78.19 \%$ of the variance of the investigated phenomenon was explained on the tested sample. The overall reliability of the Questionnaire was 0.916 (Table 3).

The first factor consists of six questions:

a) The accreditation process is an opportunity for the hospital to discover its capabilities, strengths and weaknesses;

b) After the accreditation process, hospitals can define their goals in an easier and more realistic manner;

c) Changes that occur during the preparation for the accreditation process are short-lived;

d) The accreditation process has a significant impact on hospital $P R$;

e) Benefits that the accreditation process brings are unclear to me and

f) The accreditation process has the effect of changing the overall concept of health care protection.

This factor is called the Attitude on the Positive Long-Term Impacts of Accreditation on the Planning, Implementation and Changes of the Overall Concept of Health Care.

The second factor addresses two issues:

a) The accreditation process is a significant opportunity for personal and professional improvement and

b) Responsibilities at work significantly increase post-accreditation.

This factor is called the Attitude on Increasing Professional Affirmation and Improving Work Morale.

The third factor also consists of two questions:

a) The accreditation process contributes to the increase in work safety of all employees and

b) The accreditation process significantly improves communication on all levels.

This factor is called the Attitude on Improving Communication and Safety at Work.

The scores on the components of the questionnaire were obtained by summing the answers' points by in each individual component, after which they were divided by the total number of questions that make up that particular component. The total score was obtained by summing the points of all ten questions.

Descriptive statistics on the scores
Table 2. Responses from the Questionnaire on Health Care Professionals' Attitudes on Accreditation 
Table 3. Clusters of questions, explained by variance and reliability of extracted factors of the Questionnaire on Health Care Professionals' Attitudes on Accreditation (QHCPAA)

Component 1 - the Attitude on the Positive Long-Term Impacts of Accreditation on the Planning, Implementation and Changes of the Overall Concept of Health Care;

Component 2 - the Attitude on Increasing Professional Affirmation and Improving Work Morale;

Component 3 - the Attitude on Improving Communication and Safety at Work.
Table 4. Descriptive statistics by component scores and total score of health care professionals' attitudes in the total population of respondents

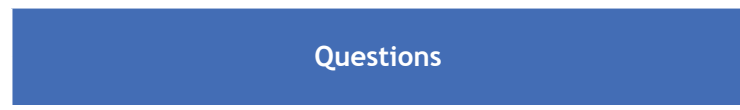

The accreditation process is an opportunity for the hospital to discover its capabilities, strengths and weaknesses.

After the accreditation process, hospitals can define their goals in an easier and more realistic manner.

Changes that occur during the preparation for the accreditation process are short-lived.

The accreditation process has a significant impact on hospital PR.

Benefits that the accreditation process brings are unclear to me.

The accreditation process has the effect of changing the overall concept of health care protection.

The accreditation process is a significant opportunity for personal and professional improvement.

\begin{tabular}{|c|c|c|}
\hline \multicolumn{3}{|c|}{ Component } \\
\hline 1 & 2 & 3 \\
\hline
\end{tabular}

0.840

0.652

0.827

0.793

0.804

0.824

Responsibilities at work significantly increase postaccreditation.

The accreditation process contributes to the increase in work safety of all employees.

The accreditation process significantly improves communication on all levels.

Cronbach's a

$\%$ explained variance

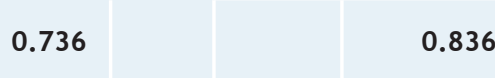

$\begin{array}{ll}0.705 & 0.729\end{array}$

0.649

0.856

0.824

\begin{tabular}{|c|c|c|}
\hline & Mean & SD \\
\hline Score for the first component & 0.71 & 0.72 \\
\hline Score for the second component & 0.41 & 0.23 \\
\hline Score for the third component & 0.09 & 0.18 \\
\hline $\begin{array}{l}\text { Overall score of the Health Care } \\
\text { Professionals' Attitudes on } \\
\text { Accreditation }\end{array}$ & 7.34 & 5.99 \\
\hline
\end{tabular}

of individual components and the total score of health care providers' attitudes toward accreditation are presented in Table 4.

By analysing the differences in scores between the group of health workers employed at HC-A and those employed at HC$\mathrm{B}$, it was found that employees of HC-A had lower scores on all components, equal to the overall score on health care professionals' attitudes on accreditation (Table 5).

\section{DISCUSSION}

The analysis of the frequency distribution of health workers surveyed in this research by occupational categories in both institutions has shown that $30 \%$ of the total number of health workers surveyed were doctors, while nurses and health technicians made up $70 \%$ of the surveyed population. The data provided is consistent with the representation of doctors in relation to nurses and health technicians in the observed hospitals.

Table 5. Descriptive statistics by component scores and total score of health care professionals' attitudes between HC-A and $\mathrm{HC}-\mathrm{B}$ with levels of significance

\begin{tabular}{|l|c|c|c|c|}
\hline & Institution & Mean & SD & P \\
\hline Score for the first component & HC-A & 0.15 & 0.29 & \multirow{2}{*}{0.000} \\
\hline \multirow{2}{*}{ Score for the second component } & HC-B & 1.44 & 0.40 & \\
\hline \multirow{2}{*}{ Score for the third component } & HC-A & 0.28 & 0.21 & \multirow{2}{*}{0.000} \\
\hline Overall score of the Health Care Pro- & HC-B & 0.59 & 0.12 & \\
\hline fessionals' Attitudes on Accreditation & HC-A & 0.02 & 0.07 & 0.000 \\
\hline
\end{tabular}


By conducting a principal component analysis on the data completed by 477 employees at $\mathrm{HC}-\mathrm{A}$ and $\mathrm{HC}-\mathrm{B}$, ten questions that comprised the three main components were identified out of a total pool of 23 questions. It has shown that the Questionnaire has high structural or structural validity (KaiserMeyer-Olkin measure of adequacy $=0.909 ; \mathrm{df}$ $=45 ; \chi^{2}=3226.590 ; \mathrm{p}=0.000$ ), implying that it is a reliable testing instrument of employees' views on accreditation, and can be used in future research. In addition, the overall reliability of the QHCPAA was very good (Cronbach alpha $=0.916$ ), while the reliability of its extracted components was also satisfactory (Table 3).

Some surveys of health care professionals' attitudes on accreditation have indicated that a large number of them believe that accreditation has increased the workload and paperwork, reduced flexibility in work, and contributed to employees' attention going more towards the implementation of the process and less towards improving the quality [14].

The above-mentioned data indicates the importance of educating health care professionals on accreditation before starting the procedure, as well as allowing them to learn about the experiences of colleagues who have gone through the process. In this way, they could be further motivated to actively participate in planned activities.

Alchenizan and Shaw have also come to the same conclusion. In their review, they have stated that it is necessary to inform health care professionals, especially doctors, about the potential benefits of accreditation before starting the process [10]. However, all the aforementioned experiences from previous studies have not been obtained through the use of content-validated instruments for measuring health care professionals' attitudes on accreditation.

On the other hand, the use of QHPCAA in our study makes it possible to obtain reliable and valid insights into employees' attitudes about the three essential factors of accreditation, in which health care professionals should be, or already have been included.

The first factor that stands out is called the Attitude on the Positive Long-Term Impacts of Accreditation on the Planning, Implementation and Changes of the Overall Concept of Health Care and it covers six questions:
The accreditation process is an opportunity for the hospital to discover its capabilities, strengths and weaknesses; After the accreditation process, hospitals can define their goals in an easier and more realistic manner; Changes that occur during the preparation for the accreditation process are short-lived; The accreditation process has a significant impact on hospital PR; Benefits that the accreditation process brings are unclear to $m e$, and The accreditation process has the effect of changing the overall concept of health care protection.

According to research done by Verstraete and his associates, accreditation improved adherence to work procedures [14]. Furthermore, a study conducted in India among doctors, hospital directors and insurance representatives has shown that respondents had given a high degree of support to the accreditation process [15]. In addition, it is easier for accredited hospitals to better define the role of their institution and the planning of services, which can consequently enable the management to organize health services more adequately $[16,17]$.

The results of a study conducted by Pomeyand et al. showed that preparing for the process of accreditation itself was an opportunity for employees to think individually about the organization of work despite their previous beliefs that accreditation had no substantive point [18].

An analysis of the impact that the experiences gained during the accreditation process had on changing health care professionals' attitudes regarding accreditation showed that health care professionals employed at HC-A who had completed the accreditation had more positive views about the process than health care professionals employed at HC-B who had no such experience, in the total score as well as the the individual components scores (Table 5). This points to the fact that participating in the accreditation process contributes to a more positive opinion of it. However, it also shows the need to introduce a survey of employees' attitudes about accreditation as an inevitable step before deciding whether to enter into the accreditation process immediately, or to organize educational seminars that would provide employees with new information aimed at maximizing their support in the institution's accreditation, prior to the process.

Another factor that stood out from the analysis of the main components is the At- 
titude on Increasing Professional Affirmation and Improving Work Morality, and this factor addresses two issues: The accreditation process is a significant opportunity for personal and professional improvement and Responsibilities at work significantly increase post-accreditation.

The employees of the accredited institution had a better view of the possibilities of increasing professional affirmation through the accreditation process, as well as the improvement of work morale. This is important because, according to Stoelwinder, doctors believe that they are only responsible for professional work with patients and cooperation with colleagues, while the work organization of the institution in which they are employed is not within their responsibility [19]. An Australian study has found that working with colleagues is one of the factors contributing to greater motivation for participating in the accreditation process. Moreover, their interest in participating in the accreditation process is partly a result of the benefits they had gained from previous engagements [7].

The third factor that stands out is called the Attitude on Improving Communication and Safety at Work, and it also addresses two questions: The accreditation process contributes to the increase in work safety of all employees and The accreditation process significantly improves communication on all levels. We have also shown that employees in HC-A have a better view of the impact of accreditation on improving communication and safety at work.

According to the results of our study, health care professionals who had experience with accreditation also have more affirmative views on the process. They believe that accreditation has long-lasting impacts on the planning, implementation, and change of the overall concepts of health care. It is necessary to address the importance of conceptual reforms in connecting quality of care with health care costs. This is important, since the accreditation process itself carries considerable costs for the institution. In a study of health care professionals' economic reasoning, Vuković and Jakovljević have shown that the health care professionals observation about management's neglect of quality costs is the most important factor in their economic reasoning [20]. They further emphasize that economic restrictions on health care that were imple- mented in Serbia between 2010 and 2013, due to the recent economic crisis, are the reason why the attitudes of health care professionals regarding the preservation of the quality of health care have significantly worsened [21]. Vuković explains the worsening reasoning in terms of greater neglect of quality costs by management in health care institutions as a disastrous consequence of economic restrictions (if implemented), and if, in order to reduce direct costs in health care institutions, the implementations of reformative, long-term, conceptual measures in the field of quality management that would have lasting economic benefits for the institution, should be applied simultaneously [22].

According to this, it is important to emphasize that health care professionals who have had experiences with accreditation perceive the accreditation process itself as an intervention that has a positive long-term impact on planning and implementation in the health care institution. Therefore, the lack of funds for covering the costs of accreditation (due to lower annual payments during economic restrictions by the National Health Insurance Fund and the Ministry of Health of the Republic of Serbia) poses a barrier to the process only in institutions where management teams neglect the costs of health care quality and have insufficient knowledge and/ or inadequately apply the concept of continuous quality improvement in the process of health service delivery. On the other hand, according to our results, health care professionals are of the opinion that such leadership not only represents a barrier to accreditation but also poses an obstacle to planning and developing the concept of permanently obtaining quality culture, as well as an obstacle to their professional affirmation and improvement of work morale in an institution [23].

Although the health care professionals' attitudes on the accreditation process could potentially affect poor outcomes of the health care institutions in which they work, unfortunately, in regards to current accreditation standards, any standards that would adequately relate to the achieved levels of quality health care within the institution have not been defined yet [24].

Regarding the limitations of our study, we emphasize that while no instruments for measuring the health care providers' attitudes on accreditation have been validated so 
far, other validated instruments for measuring the health care professionals' attitudes on professional satisfaction, quality, or cost of health care quality have not been applied in our study. For the aforementioned reasons, the direct correlation of the components of the employees' attitudes on accreditation with the components that make up the content of the other validated instruments could not be made, but could be discussed indirectly based on of logical implications. On the other hand, context factors (economic restrictions, limiting the number of health care workers employed to the bare minimum, as well as accumulating administrative work for health care professionals due to layoffs of non-medical staff) could certainly have a significant impact on health care professionals' views of professional satisfaction, motivation, as well as the quality and/or cost of quality health care in health care institutions [25]. Therefore, we consider future research to be of utmost importance. We hope that the aforementioned instruments $(\mathrm{QH}$ PCAA) would be used to adequately assess the impact that accreditation, as an intervention has on changing the employees' attitudes about health care quality, professional motivation and effectiveness [26].

\section{CONCLUSION}

The Questionnaire on Health Care Professionals' Attitudes on Accreditation of Health Care Institutions used in this research has high content and structural validity and is a reliable instrument for examining the hospital health care professionals' attitudes regarding the accreditation process. Its use makes it possible to obtain a clear insight into the hospital employees' attitudes regarding the essential aspects of accreditation in a valid and reliable manner, such as attitudes about the positive longterm effects of accreditation on the planning, implementation and changes of the overall concept of health care, as well as enhancing professional affirmation and improvement of work morale, communication and work safety. Experience with accreditation enables health care professionals to view this process as a reformative intervention that has a positive and long-term impact on the planning and realization of the health care institution. It is of utmost importance that the management of the health care institution starts planning the implementation of the accreditation process, and should, prior to initiating the process itself, examine employees' attitudes regarding accreditation and provide employees with timely and specific information, but also identify and remove potential barriers that it may produce in the institution's accreditation process.

\section{CONFLICT OF INTEREST}

The authors deny any potential conflicts of interest.

\section{FINANCIAL DISCLOSURE STATEMENT}

The authors did not receive any funds for this study.

\section{REFERENCES}

1. Rules on Accreditation of Health Care Institutions, Official Gazette RS, no.112/09.

2. Greenfield D, Braithwaite J. Health sector accreditation research: a systematic review. International journal for quality in health care. 2008; 20(3), 172-183.

3. Agency for Accreditation of Health Institutions of Serbia. Training courses for external evaluators; 2010.

4. Shaw CD. Accreditation in European Healthcare, Jt Commission J Qual Pat Saf. 2006; 32: 266-75.

5. Corrêa JÉ, Turrioni JB, Mello CHP, Santos ACO, da Silva CES, de Almeida FA. Development of a System Measurement Model of the Brazilian Hospital ACcreditation System. Int J Environ Res Public Health 2018; 15(11): 2520. doi:10.3390/ijerph15112520.

6. Bahadori M, Teymourzadeh E, Ravangard R, Saadati M. (2018). Accreditation effects on health service quality: nurse viewpoints. International Journal of Health Care Quality Assurance 2018; 00-00. doi:10.1108/ijhcqa-07-2017-0126.

7. Greenfield D, Pawsey M, Braithwaite J. What motivates professionals to engage in the accreditation of healthcare organizations? Int J Qual Health Care 2011; 23(1): 8-14.

8. Hochhauser M, Khashab K, Baba N, Khoury A. Accreditation in hospitals: attitudes and satisfaction of staff members from the process. Harefuah 2018; 157(6): 383-387

9. Hinchcliff R, Greenfield D, Moldovan M, Westbrook JI, Pawsey M, Mumford V, et al. Narrative synthesis of health service accreditation literature. BMJ QualSaf 2012; 21(12): 979-991.

10. Alkhenizan A, Show C. The Attitude of Health Care Professionals Towards Accreditation. A Sys- 
tematic Review of Literature. J Family Community Medicine 2012; 19(2): 74-80.

11. Al-Faouri I, Al-Dmour A, Al-Ali N, AbuALRub R, Abu Moghli F. Effect of Health Care Accreditation Council survey site visit on perceived stress level among Jordanian healthcare providers. Nursing Forum 2019; 54(1): 30-37.

12. Bogh SB, Blom A, Raben DC, Braithwaite J, Thude B, Hollnagel E, Plessen CV. Hospital accreditation: staff experiences and perceptions. Int J Health Care Qual Assur 2018; 31(5): 420-427. doi: 10.1108/IJHCQA-06-2017-0115.

13. Jaafaripooyan E, Agrizzi D, Akbari-Haghighi F. Healthcare accreditation systems: further perspectives on performance measures. Int $\mathrm{J}$ Qual Health Care 2011; 23(6): 645-56.

14. Verstraete A, van Boeckel E, Thys M, Engelen F. Attitude of laboratory personnel towards accreditation. International Journal of Health Care Quality Assurance 1998; 11(1): 27-30.

15. Nandraj S, Khot A, Menon S, Brugha R. A stakeholder approach towards hospital accreditation in India. Health Policy Planning 2001; 16(suppl 2): 7079.

16. Duckett SJ. Changing hospitals: the role of hospital accreditation. Social Science \& Medicine 1983; 17(20): 1573-79.

17. Hijazi HH, Harvey HL, Alyahya MS, Alshraideh HA, Al Abdi RM, Parahoo SK. The Impact of Applying Quality Management Practices on Patient Centeredness in Jordanian Public Hospitals: Results of Predictive Modeling. INQUIRY: The Journal of Health Care Organization, Provision, and Financing. 2018; 55, 0046958018754739.

18. Pomey MP, Contandriopoulos AP, Francois P, Bertrand D. Accreditation: a tool for organizational change in hospitals? International Journal of Health Care Quality Assurance 2004; 17(3): 113-24.

19. Stoelwinder J, McNeil JJ, Ibrahim JA. A Study of Doctors' Views on How Hospital Accreditation Can Assist Them Provide Quality and Safe Care to Consumers. Monash University, Department of Epidemiology and Preventive Medicine; 2004.

20. Vuković MH, Jakovljević MB. Structural validity and reliability of the healthcare professionals' economic reasoning questionnaire. Hospital Pharmacology 2015; 2(3): 308-16.

21. Jakovljevic M, Vukovic M, Chen CC, Antunovic $M$, Dragojevic-Simic V, Velickovic-Radovanovic R, et al. Do Health Reforms Impact Cost Consciousness of Health Care Professionals? Results from a NationWide Survey in the Balkans. Balkan Medical Journal 2016; 33(1): 8-17.

22. Vuković M. PhD Thesis: "Psychometric analysis of factors of economic reasoning in the clinical decision making process". Faculty of Medical Sciences, University of Kragujevac, 2014.
23. Vuković MH, Vuković AD. Need for Reconceptualization of Professional Satisfaction and/or Work Effects in Healthcare Organizations. Hospital Pharmacology - International Multidisciplinary Journal 2017; 4(3): 573-580. (www.hophonline.org)

24. Marković-Petrović $G$, Vuković $M$, Jović-Vraneš $A$. The impact of accreditation on health care quality in hospitals. Vojnosanitetski pregled 2018; 75(8): 803-808. DOI:10.2298/VSP160728390M

25. Jakovljevic M, Vukovic $M$, Antunovic $M$, Dragojevic Simic V, Velickovic Radovanovic R, SiladjiMladenovic D, Jankovic N, Rankovic A, Kovacevic A, Antunovic M, Markovic V, Chia-Ching C, Tetsuji Y. Do Policy Measures Impact on Cost Consciousness of Health Care Professionals? Value in health 2013; 16(7): A542-A542.

26. Marković Petrović G. PhD Thesis: "Accreditation of healthcare institutions as a contributing factor to the quality of work in hospital care". Faculty of Medicine, University of Belgrade, 2017. 
Respected colleague

This questionnaire is one of the instruments for a survey on the connection between ACCREDITATION and QUALITY of health care.

The questionnaire is anonymous and the results will be used for scientific purposes only.

Your consent to participate in the survey is implied,should you return the completed questionnaire.

Thank you for your contribution.

Questionnaire for Health Professionals

I Personal information

1.1. Gender Male /Female (please circle)

1.2. Age (please write)

1.3. Occupation (please choose one of the offered modalities)

a. Medical Doctor

b. Doctor at any clinical management job

c. Nurse (technician, lab technician)

d. Nurse (technician, lab technician) in any management job

II Questionnaire

(please write the "+" sign under one of the three modalities for each statement and, if desired, comment on it in the designated column)

No Statement

The accreditation process is an opportunity for the

2.1 hospital to discover its capabilities, strengths and weaknesses.

2.2 After the accreditation process, hospitals can define their goals in an easier and more realistic manner.

2.3 All profiles of employees are covered by the accreditation process.

The preparation for the accreditation process

2.4 contributes to the quality improvement of hospital operations.

2.5 Changes that occur during the preparation for the accreditation process are short-lived.

2.6 The accreditation processhas a significant impact on hospital PR.

2.7 The accreditation process significantly improves the specialists'quality of work as well as patient safety.

2.8 The accreditation process significantly increases workload.

2.9 The accreditation process does not bring any significant changes in regards to patient care.

2.10 Health care quality assessment is a continuous process and it's a part of daily activities.

The accreditation process increases satisfaction

2.11 with the provided care in both healthcare professionals and patients.

The greatest importance of the accreditation pro-

2.12 cess is in the work organization within the health care institution.

2.13 Benefits that the accreditation process brings are unclear to me.

2.14 Standards, criteria and guides cannot improve quality on their own.
APPENDIX 1. The Questionnaire on Health Care Professionals' Attitudes on Accreditation of Health Care Institutions 
2.15 The accreditation process significantly improves communication on all levels.

2.16 The accreditation process has the effect of changing the overall concept of health care protection.

2.17 The accreditation process is a significant opportunity for personal and professional improvement.

2.18 Teamwork is not well received despite the accreditation process.

2.19 Responsibilities at work significantly increasepostaccreditation.

2.20 There is a lack of education based on the employees' needs.

2.21 Patient safety increases significantly after the accreditation process.

Prior to starting the procedure, healthcare profes-

2.22 sionals do not know much about the accreditation process.

2.23 The accreditation process contributes to the increase in work safety of all employees.

Thank you for your time and effort! 


\title{
Razvoj upitnika Stavova zdravstvenih radnika o akreditaciji zdravstvenih ustanova
}

\author{
Gordana D. Marković-Petrović ${ }^{1}$, Gordana B. Belamarić \\ ${ }^{1}$ Služba za specijalističku i konsultativnu delatnost, Dom zdravlja Zemun, Beograd, Srbija \\ ${ }^{2}$ Gradski zavod za javno zdravlje Beograd, Beograd, Srbija
}

\section{KRATAK SADRŽAJ}

Uvod: Akreditacija predstavlja postupak ocenjivanja kvaliteta rada zdravstvene ustanove, na osnovu primene optimalnog nivoa utvrđenih standarda rada zdravstvene ustanove u određenoj oblasti zdravstvene zaštite, odnosno grani medicine. Kako su glavni nosioci posla tokom akreditacije zdravstvenih ustanova zdravstveni radnici, veoma je važno, pre započinjanja ovog procesa da se proceni struktura i stekne uvid u najvažnije komponente njihovih stavova u vezi sa akreditacijom.

Metod: Studija je sprovedena u dve bolnice sekundarnog i tercijarnog nivoa zdravstvene zaštite, od kojih je jedna akreditovana, a druga nije. Dizajnirana je kao opservaciona studija i obuhvatila je anketiranje dve grupe ispitanika. Eksperimentalnu grupu su činili zaposleni zdravstveni radnici u bolničkoj zdravstvenoj ustanovi u kojoj je sprovedena akreditacija, dok su drugu, kontrolnu grupu činili zdravstveni radnici zaposleni u bolničkoj ustanovi u kojoj akreditacija nije sprovedena. U istraživanju je, kao instrument za merenje stavova zdravstvenih radnika o akreditaciji, korišćen originalan upitnik sa pretpostavljenom strukturom od 23 pitanja. Redukcija podataka i procena strukturne validnosti pomenutog instrumenta, sprovedena je analizom glavnih komponenti, dok je njegova relijabilnost procenjena korišćenjem koeficijenta Cronbach alfa.

Rezultati: Upitnik o stavovima zdravstvenih radnika o akreditaciji sa proizašlih 10 pitanja ima visoku konstrukcionu, odnosno strukturnu validnost (Kaiser-Meyer-Olkin mera adekvatnosti $=0.909)$. Ukupni Cronbach alfa bio je 0.916. Analizom glavnih komponenti sa ekstrahovanih deset pitanja, izdvojena su tri faktora ili komponente: (1) stav o pozitivnim dugotrajnim uticajima akreditacije na planiranje, realizaciju i promenu ukupnog koncepta zdravstvene zaštite, (2) stav o povećanju profesionalne afirmacije i unapređenju radnog morala i (3) stav o unapređenju komunikacije i sigurnosti na poslu. Zdravstveni radnici zaposleni u bolnici koja je bila akreditovana u odnosu na zaposlene u bolnici koja nije akreditovana, imali su značajno pozitivnije stavove o akreditaciji po svim pomenutim komponentama.

Zaključak: Upitnik stavova zdravstvenih radnika o akreditaciji ima visoku sadržinsku i strukturnu validnost. Njegovom primenom pre postupka akreditacije bolnice, mogu se proceniti potencijalni pozitivni resursi u ustanovi, a koji proizilaze iz pozitivnih stavova zdravstvenih radnika o akreditaciji. Takođe, ovim instrumentom, mogu se proceniti i potencijalne barijere uspešnom sprovođenju akreditacije, a koje su rezultat pretežno negativnih stavova zdravstvenih radnika o procesu akreditacije.

Ključne reči: akreditacija, stavovi, zdravstveni radnici, upitnik, analiza glavnih komponenti 